\title{
O CRIOULO GUINEENSE EM RELAÇÃO AO PORTUGUÊS E ÀS LÍNGUAS NATIVES
}

I - Quando se pergunta guineese sobre a realidade lingüística de seu país, em geral a resposta vem pronta: "Na Guiné-Bissau, temos o crioulo, que é a língua nacional, o português, que é a língua oficial, e as línguas nativas, que são faladas pelas diversas etnias". Diante desta resposta poderíamos sair com a falsa impressão de que os domínios do crioulo, do português e das línguas nativas estão claramente delimitados. Nada, porém, mais longe da verdade. Trata-se apenas de um lugar-comum que se ouve freqüentemente na rua e até entre intelectuais.

Outro lugar-comum é o de que "crioulo é português mal falado", "crioulo é português errado" (M. F.), enfim, "criol i portugis mal papiadu" (o povo). Como já salientaram ROUGE (1988, p. 5) e SCANTAMBURLO (1981, p. 9), entre outros, trata-se de uma concepcão inaceitável. Ela é uma das manifestacões da ideologia colonialista que, como sabemos, sempre considerou os colonizados como seres de segunda categoria. Tudo que lhes era, e é, específico é despiciendo, como sua cultura, sua língua, etc. O pior é que essa ideologia foi assimilada pelos próprios colonizados, que a reproduzem acriticamente, até mesmo após o movimento de libertação nacional.

Os colonizadores foram muito eficientes na destruição das culturas nativas e ao impingirem a idéia de que tudo que vem da Europa, isto é, do colonizador, é melhor, o que implica que tudo que tenha cor local é inferior. A ideologia da inferioridade do que é local em relação ao que é europeu está tão arraigada que até alguns intelectuais a aceitam. Um dirigente do primeriro escalão do governo me disse textualmente o seguinte: "O crioulo não é uma língua. Ele não tem uma gramática, não tem um dicionário nem uma escrita. É apenas o meio de comunicação (sic̣!) de grande parte dos guineenses". Mesmo deixando de lado o fato de ele não saber que "gramática" e "dicionário" (léxico) de uma língua não são necessariamente livros impressos com estes nomes, nota-se que este dirigente não está imune á ideologia colonialista. Até mesmo um membro do PAIGC (Partido Africano para a Independencia da Guiné e Cabo Verde) disse: "O crioulo não está codificado, não tem regras, não tem gramática". Tudo isso mostra que a ideologia colonialista calou fundo nos africanos, atingindo até mesmo os revolucionários. Será necessário um longo processo de reeducação a fim de reverter tal situação.

A crenca na inferiodidade do crioulo em relação ao português é apenas uma das manifestações da ideologia colonialista, que se mostra com mais força ainda em outros setores. Entre os europeus que encontrei na Guiné-Bissau, é corrente a idéia de 
que o africano é indolente, irresponsável e de pouca inteligência. Dizem que nunca faz as coisas como eles lhe ensinam. Eu não vou me alongar mais sobre este tema porque ele foge dos objetivos que aqui me propus. No entanto, gostaria de algum dia fazer uma análise da situação político-econômica atual do país.

Quando analisamos o domínio das etnias locais e o comparamos com a divisão política da África, começamos a encontrar as causas dos lugares-comuns acima relacionados com a ideologia colonialista. Grande parte das dezenas de línguas faladas na Guiné-Bissau vão além de suas fronteiras. É o caso, p. ex., dos nalu/sossos, dos felupes, dos fulas, dos mandingas, etc. Os colonizadores europeus repartiram arbitrariamente a África entre si, no decorrer do século XIX. Houve vários tratatos bilaterais, mas o mais importante dales foi a Conferência de Berlim em que quinze potências ocidentais decidiram o futuro da África, sem que nenhum país africano estivesse presente. Com isso, criaram-se estados artificiais, que não correspondem a uma nação. Com efeito, o equivalente africano de nacão seriam as etnias. Como diz Carlos Lopes, "As formas de poder em evidência comecam da família para passar ao grupo étnico e finalmente à Nação" (Lopes 1987, p. 38). As etnias se viram de repente repartidas por diversos países (estados).

Todo estado pressupõe uma estrutura de poder, com um centro de decisão e toda uma malha de instâncias administrativas e de decisões políticas. A fim de interargirem entre si neste espaço artificialmente delimitado pelo colonizator, os nativos africanos tiveram que forjar um meio de comunicação precário a partir do pouco que os portugueses lhes ofereciam em termos de língua (ROUGÉ 1986). Desde os primeiros anos da colonização, os colonizadores estiveram preocupados com a escravização dos africanos e não com lhes trazer a cultura européia. Não houve a preocupação de ensinar o português aos nativos. Por causa disso e do fato de falantes de diversas línguas diferentes entre si terem que interagir neste espaço, ou seja, no "país" Guiné-Bissau, foi surgindo naturalmente o crioulo como uma espécie de língua geral de comunicação interétnica.

O português continua sendo até hoje uma língua estrangeira para os guineenses que só é aprendida na escola. Do português pidginizado que ouviram do colonizador os africanos que se encontravam sob o poder lusitano forjaram seu próprio meio de comunicação interétnica e interracial (com os portugueses), ou seja, o crioulo. Com isso, a língua portuguesa lhes permaneceu estranha. Apesar de ainda ser a língua de ensino, da imprensa escrita (só há um jornal, Nô Pintcha), da administração, enfim, apesar de ser a língua oficial de Guiné-Bissau, o português é uma língua estrangeira (MACEDO, a sair). Talvez não tanto quanto o francês, cuja influência no país é muito grande devido ao fato de a Guiné-Bissau ser uma ilha no meio de paises de língua oficial francesa (Guiné-Conacri, Senegal, etc.).

Vê-se, assim, que o portugês é a língua de uma pequena minoria (o analfabetismo chega a quase $80 \%$ da população). Os guineenses que o têm como língua materna não chegam a 300 . Mesmo assim, ele tem uma grande influência na vida do país, 
pois tudo está escrito em português. De um modo geral, os monolíngües em crioulo e os bi- ou plurilíngües (os que falam crioulo e uma ou mais línguas nativas) têm pelo menos um precário conhecimento passivo do português, pelo menos nas cidades e arredores. Em várias ocasiões eu me dirigi em português a pessoas, em geral velhas, que só falavam crioulo ou, adicionalmente, uma ou outra língua nativa. A resposta vinha invariavelmente em crioulo. Freqüentemente eu thes perguntava se falavam português e a resposta era negativa. Por outras palavras, eles me entendiam, isto é, tinham um domínio passivo do português, mas eram incapazes de se expressarem nele.

Certa feita eu telefonei para um ministério e perguntei: “O sr. L. F. está?". A resposta foi: "I ka tchiga inda" (ele ainda não chegou), dada por uma funcionária. Em outros dois telefonemas mantive os seguintes diálogos, sempre com uma funcionária:

$$
\begin{aligned}
1^{\circ} \text { diálogo: } \mathrm{HHC} \text { : "Eu queria falarcom o sr. M. N.!" } \\
\text { resp.: "I ka sta!" (ele não está) } \\
2^{\circ} \text { diálogo: } \mathrm{HHC} \text { : “O sr. J. A. está?“ } \\
\text { resp.: "I bin ma i bai!" (ele veio mas já saiu) }
\end{aligned}
$$

Enquanto esperava por uma audiência com um secretário de estado, ouvi de um funcionário da recepção: "Dizer 'n ka sibi' é muito mais fácil do que 'eu não sei'!". Quando já estava dentro do único avião que o país possui (Fokker) ouvi de uma administradora do aeoroporto as seguintes frases: "I ta fitcha!" (ela está fechada: a porta), "Lina, bin fitcha cusa li!" (Lina, vem fechar isto aqui!).

Como se vê, a língua corrente nas cidades é o crioulo, mesmo entre as pessoas cultas e as da administração em geral. Como disse meu informante, Domingos, "Criol i língua ki tudu ginti ta papia na Guiné" (o crioulo é língua que todos falam na Guiné). O português é apenas a língua "de trabalho", para redação de documentos, para relacionamento com estrangeiros, etc. Eu passei alguns dias na redação do Nô Pintcha e pude verificar que todos os empregados falam exclusivamente crioulo entre si, embora o jornal seja todo escrito em português. O mesmo se passa em outras instituções, como o Banco da Guiné-Bissau, os correios, a sede do PAIGC, etc.

No campo, sobretudo nas regiơes que mantêm pouco contato com as cidades, as línguas faladas são o felupe, o fula, o balanta, etc., ou seja, cada etnia fala sua língua. Para a comunicação interétnica, a língua usada é o crioulo. Mesmo em alguns bairros das cidades podemos ver pessoas se comunicando em línguas nativas. $\mathrm{Na}$ cidade de Bafatá há vários bairros inteiramente fulas. Nestes a comunicação se faz via de regra em fula, embora a maioria entenda também o crioulo. Na zona rural circundante quase só se fala o fula.

O fato é que o estado Guiné-Bissau é o resultado histórico da violenta imposição colonial da cultura européia (LOPES 1987, p. 61). Não obstante, ele é uma realidade irreversível no atual jogo de interesses mundial. Com isso, temos um quadro lingüístico extremamente complicado e sem parelha em todo o mundo. Neste quadro vê-se que o português representa o estado, o crioulo representa a nação e 
as línguas nativas, e o próprio crioulo, representam o povo. Devo acrescentar, no entanto, que "estado" aqui não equivale ao domínio da nação, muito menos do povo, já que este (as etnias) extrapola as fronteiras guineenses.

II - Diante de tudo que foi dito até agora ainda não temos una idéia do que seja o crioulo da Guiné-Bissau. Afirmar que ele é a língua geral, a língua franca ou a língua veicular desse país não nos esclarece em nada. Dizer que é uma deformação do português efetuada pelos nativos africanos é repetir o ramerrão da ideologia colonialista. Com efeito, o reacionarismo sempre considerou qualquer evolução como deformação. No entanto, como todas as línguas do mundo, o crioulo representa uma evolução histórica, na caso do português no ambiente africano. E como qualquer língua do mundo ele apresenta também difereciações históricas (diacrônicas), geográficas (diatópicas) e sociais (diastráticas). Ou seja, o crioulo é uma língua como qualquer outra.

Do ponto de vista histórico, os próprios falantes têm consciência de que o crioulo nasceu em Cachéu. O meu informante sempre chamava a atenção para a diferença entre o crioulo dos velhos (homi garandi) e o dos jovens, sobretudo dos estudantes. Teremos oportunidade de ver diversos exemplos de ambos usos abaixo. A alta autoridade governamental a que me referi acima afirmou que não entende 0 crioulo antigo, de Cachéu, a que ele chamou de "crioulo fundo".

A variação regional é bem mais palpável do que a histórica uma vez que se trata de realidades simultaneamente presentes no país e até fora dele. De acordo com as fontes disponíveis, há pelo menos as seguintes variedades de crioulo: 1 . de Cachéu/São Domingos, em direção à fronteira norte e à costa; 2. de Bafatá e Geba; 3. de Bissau e Bolama, o mais difundido. Devemos acrescentar que próximo ao de $\mathrm{Ca}$ chéu/São Domingos temos o de Ziguinchor, já no Senegal (SCANTAMBURLO 1981, p. 13 e WILSON 1962, p. VII). Neste contexto deve ser mencionado também o crioulo do arquipélago de Cabo Verde. Apesar de apresentarem várias diferenças um em relação ao outro, é possível a intercomunicação. As relações históricas entre Guiné-Bissau e Cabo Verde sempre foram tão intensas que as respectivas lideranças revolucionárias tentaram fazer de ambos um único estado. Tanto assim que até hoje o nome do partido guineense é PAIGC (LOPES 1987, p. 47-49). Há ainda variações menores dentro de cada uma das citadas. Apesar da importância da variação diacrônica e da diatópica, meu objetivo principal é a variação social.

Mesmo fazendo abstração da variação diacrônica e da diatópica, podemos continuar perguntando o que é o crioulo guineense. A resposta continua sendo difícil. Com efeito, a própria palavra em uso para denominá-lo já evidencia a sua complexidade. Ela aparece sob as formas "crioulo", "criolo", "criol" (kriol) e "kiriol“. Esta variação representa gradações diastráticas no uso do próprio crioulo. Ou seja, o crioulo guineense não é uma realidade simples e compacta, mas um continuum que vai desde "criolo" até "kiriol". 
Quando um especialista em crioulística quer fazer uma monografia sobre um aspecto qualquer da gramática do crioulo tem que escolher se vai descrever um "crioulo puro", ou seja, "kiriol", ou um crioulo fortemente influenciado pelo português(criol) ou, então, um crioulo marcado pelas línguas nativas. A fim de pôr um pouco de ordem no emaranhado aparente que é esta língua e na complexidade linguística de Guiné-Bissau em geral, proponho o seguinte esquema da categorias: 1. línguas nativas, 2 . crioulo natizivado, 3 . crioulo tradicional, 4 . crioulo aportuguesado, 5. português acrioulado, 6 . portugues lusitano (brasileiro, angolano, moçambiçano, etc.) e outras línguas, como o francês e o wolof do Senegal. Como já disse acima, trata-se de um problema surgido com a criação artificial do país(estado), com suas fronteiras delimitadas à revelia das etnias (LOPES 1987, p. 59-61). Mas, como se trata de um fato, temos que tentar compreendê-lo e, se possível, transformá10 .

Diante destas categorias podemos entender as diversas variantes da própria palavra "crioulo". Esta seria uma forma do português lusitano (6). A forma "criolo" pertenceria ao português acrioulado (5). A forma "criol" (kriol, kriôl) é usada num crioulo aportuguesado (4). A forma "kiriol", por fim, é a que se usa no crioulo "puro", a que chamei de "crioulo tradicional" por falta de expressão mais adequada. Em seguida entro na parte principal deste ensaio, isto é, retomarei cada um dos itens 1 a 6 e os examinarei pormenorizadamente.

\section{III -1 . Línguas nativas}

"Língua i raça" (um popular no merc. do Bandim, Bissau).

Faz parte do folclore lingüístico guineense a afirmação de que nesse país se falam cerca de 30 línguas. Podemos ouvi-la de populares na rua, mas também de estudiosos da problemática sociolingüística local (SCANTAMBURLO 1981, p. 15). Como se trata de uma realidade muito pouco estudada, é bem possível que várias dessas "linguas" não passem de dialetos de uma língua mais abrangente. Por exempio, os banhuns, os felupes e os baiotes são subgrupos da etnia balanta (LOPES 1987, p. 22).

Se tomarmos a possibilidade de intercompreensão como critério para definir uma língua, brame, manjaco e papel são única língua (LOPES 1987, p. 22). Além disso, há a dominação de uma língua sobre outra. Os nalus, p ex., assimilaram a língua dos sossos, mais falada na Guiné-Conacri. A língua papel praticamente não é mais falada, se desfigurou quase por completo devido ao fato de ser falada na região da capital (Bissau), onde o crioulo é a língua predominante.

Segundo os dados que Francisco Macedo e Ibrahima Djalô apresentam do recenseamento de 1979 , as línguas nativas não passariam de umas 15 . A Guiné-Bissau tem cerca de $36.126 \mathrm{~km}^{2}$ e uma população estimada em 910.000 habitantes. A porcentagem de monolíngües é a seguinte: 


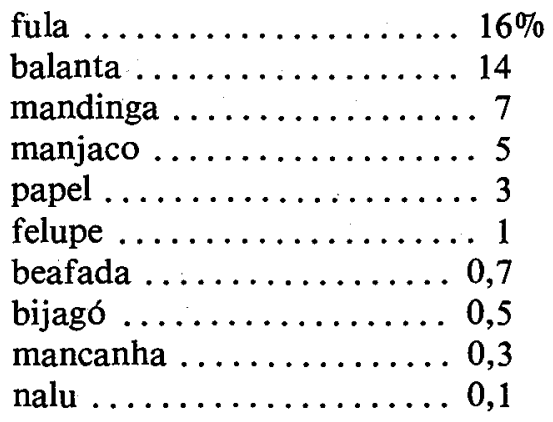

Para os bilíngües, trilíngues e multilíngues, ou seja, aqueles que falam uma língua materna e uma ou mais línguas, o quadro é o seguinte:

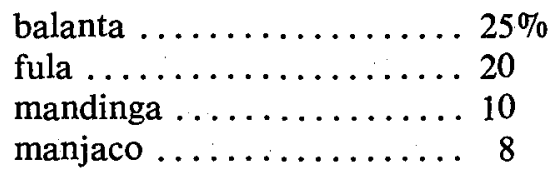

Falando só crioulo são 4,26\%. Falando crioulo e uma ou mais línguas são cerca de 44\%. (DJALÔ 1987, p. 106-107 e MACEDO a sair).

Como se vê, o fula apresenta o maior número de monolíngües. Mas, se contarmos os que falam adicionalmente uma ou mais línguas, o balanta vem em primeiro lugar.

Esse complexo mosaico étnico e linguístico favoreceu enormemente a dominação colonial portuguesa. Para garantir esta dominação os colonialistas conseguiram o apoio dos fulas (LOPES 1987, p. 20), além de terem se aproveitado dos desentendimentos entre as diversas etnias locais. "Quando da chegada dos portugueses, os Mandingas ocupavam toda a zona dos Grandes Rios, estando no apogeu de sua expansão para o Oeste. Os povos litorais, como os Balantas, ou os Beafadas, já lhes pagavam tributos“ (LOPES 1987, p. 28).

No "Programa de Lagos: Um Plano de Acção Cultural", recomenda-se o estudo das línguas nacionais, "harmonização dos sistemas de transcrição das línguas africanas, à escala regional e subregional", "introdução do ensino das línguas nacionais no ensino a todos os níveis". (Nô Pintcha 3/3/77). Mas até hoje isso permanece como ideal a ser atingido. É bem verdade que já se começa a alfabetizar adultos em fula e balanta, além do crioulo. Mas, até minha partida da Guiné-Bissau (16/4/88) ainda não se tinha nenhum resultado. 


\section{Crioulo nativizado}

A expressão "crioulo nativizado" é usada para designar o crioulo influenciado pelas línguas nativas africanas. Segundo Rougé, “... numa certa altura, no princípio de sua formação, o crioulo devia situar-se muito mais perto das línguas africanas do que se encontra hoje' (ROUGÉ 1986, p. 44). Mesmo hoje em dia, ainda se encontra uma modalidade de crioulo muito próxima das línguas nativas. No caso dos matrimônios interétnicos, em geral os cônjuges passam a falar este tipo de crioulo, pois mal estão saindo da sua língua materna. De um modo geral, é o crioulo nativizado que se usa nas tabancas (agrupamentos de casas tipicamente africanas, cobertas de palha) dos arredores das cidades e do campo. Vê-se, que a aquisição do crioulo nativizado é o primeiro passo no processo glotofágico, segundo a expressão de CALVET (1974). Ou seja, ao deixar de falar sua língua materna (balanta, fula, etc.) o indivíduo dá primeiro passo na direção da perda de sua identidade étnica. Se ele nunca mais voltar a falá-la, a perda será total, sua língua e sua cultura terão sido devoradas pela língua e pela cultura dominantes. Com efeito, "língua i raça" (a língua é a etnia, como disse o popular no mercado do Bandim). ROUGÉ (1988, p. 8) chamou o processo que leva a esta modalidade de crioulo de "africanização". Em suas palavras, "L'africanisation, qui est véhiculée par les adultes qui aprennent actuellement le kriol et dont la langue maternelle est une langue africaine“.

Para falar de cátedra sobre o crioulo nativizado é necessário uma estada de vários anos no país a fim de estudar todas as línguas que nele são faladas. Não obstante, eu colhi alguns exemplos típicos dessa modalidade do crioulo guineense. Para maiores informações sobre o assunto, pode-se consultar ROUGÉ (1987) e WILSON (1962).

Em bijagó não existe o fonema /f/. Por este motivo, no crioulo abijagosado ele é substituído por $/ \mathrm{p} /:$ /fidžu/ $\rightarrow /$ pidžu/. Quando Domingos perguntou a um inclivíduo desta etnia se podia fazer algumas gravações para nós, ele retrucou: "Pa passi ké?“ (para fazer o quê?). No crioulo abalantado, /p/ vira $/ \mathrm{b} /: /$ poti/ $\rightarrow$ /boti/ (pote). Em fula não há $/ \mathrm{t} /$, portanto, no crioulo afulado temos formas como $/ \mathrm{kantša} /$ em vez de $/ \mathrm{kanta} /$ (canta). O crioulo apapelado substitui $/ \mathrm{tš} / \mathrm{por} / \mathrm{s} /$. Assim, /tšabi $\rightarrow /$ sabi / (chave), /tšiga/ $\rightarrow$ /siga/ (chegar), etc. Aliás, falantes de quase todas as etnias da Guiné-Bissau tendem a substituir /š por $/ \mathrm{s} / \mathrm{e} / \check{z} /$ por $/ \mathrm{z} /$.

Além dessas marcas segmentais impostas pelas diversas etnias ao crioulo, temos tambén as supra-segmentais. Tanto a entoação quanto o ritmo do crioulo são fortemente influenciados pelas línguas africanas. $O$ ritmo africano é tão marcante que chega a afetar o crioulo tradicional, o crioulo aportuguesado e até mesmo o português acrioulado. O mesmo fenômeno se nota no francês falado em Dakar (Senegal), cujo ritmo é visivelmente o do wolof (é o- "français wolofiséc).

No domínio da categorização semântica também notamos diferenças. Por exempio, no crioulo abalantado em geral se cumprimenta fazendo uma pergunta re- 
lativa à posição em que a pessoa se encontra. Em vez de se dizer apenas "kuma?" (como vai?) ou "kuma di korpu?" (como está?), diz-se: a) bô sinta?" (você está sentado?), b) "bô dita?" (você está deitado?), c) "bô na mesa?" (você está à mesa?), d) "bô firma?" (você está de pé?) e assim por diante. Jean Luis Rougé nos dá centenas de exemplos de influências lexicais, morfológicas, semânticas e outras das línguas nativas sobre o crioulo (ROUGÉ 1986, 1988). BARUFFALDI (1984, p. 16-21) apresenta uma longa lista de radicais de línguas nativas no crioulo, embora com uma série de equívocos. WILSON (1962) é uma outra fonte de consulta para este assunto.

\section{Crioulo tradicional}

Por crioulo tradicional entendo o crioulo "puro". É o crioulo dos velhos, o crioulo "bem falado". Em suma, é o "crioulo fundo" (kiriol fundu), por oposição ao "crioulo leve" (kiriol lébi), que seria o crioulo aportuguesado. Freqüentemente, este crioulo é também chamado de "crioulo de Cachéu“ e de „crioulo dos velhos". De um ponto de vista negativo podemos dizer que esta modalidade do crioulo guineense é aquela que não tem marca visível nem das línguas nativas nem do português. É "o espaço-síntese das culturas que povoam a Guiné-Bissau". "Lugar de diállogo e encontro, o crioulo é também um fenômeno de aculturação e esta um índice seguro de autenticidade", tomando-se esta no sentido de sua "distância à ortodoxia gramatical da língua portuguesa“ (MONTENEGRO/MORAIS 1979, "Introdução"). De um modo geral é o crioulo de falantes que o têm como língua materna, sobretudo da segunda geração de falantes em diante, e quando são analfabetos. J. L. Rougé chamou-o de "desenvolvimento autônomo": "Le développement autonome qui est le fait des enfants, en particulier de ceux dont les familles n'utilisent le kriol que comme langue véhiculaire alors que pour eux il est langue première" (ROUGÉ 1988, p. 8).

O crioulo tradicional se distingue do crioulo aportuguesado praticamente em todos os niveis. No nível fonético-fonologico, há uma série de especificidades. Em primeiro lugar, notamos uma repugnância pelos fonemas $/ \lambda, \breve{z} /$, como em /fidžu/ (filho), /bedžu/ (velho), /džugu/ (jogo), /bedžu/ (beijo), etc. O fonema / ̌̌/ tende a /tš/. Como exemplos podemos citar, entre outros, /tšikeru/ (chiqueiro), /tšuba/ (chuva) e /matšu/ (macho). O fonema $/ v /$, por seu turno, em geral vira $/ \mathrm{b} /$. Como exempio citemos /baka/ (vaca), /koba/ (cova) e / kubi/ (couve). A oposição existente em português entre a vibrante simples $/ \mathrm{r} /$ (caro) e a múltipla (carro) se desfaz.

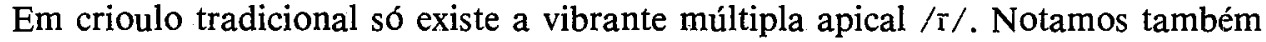
uma tendência ao ensurdecimento (dessonorização) do $/ \mathrm{z} /$ português, como em /kasa/ (casa), /kusa/ (coisa), /mesa/ (mesa), /fasi/ (fazer) e /sagaya/ (zagaia).

Uma característica marcante do crioulo é a presença da velar nasal $/ \eta /$, inexistente em português. É um dos poucos fonemas que podem ocorrer em qualquer posição: no início de palavra, antes de vogal como em /noroto/ (foice); antes de con-

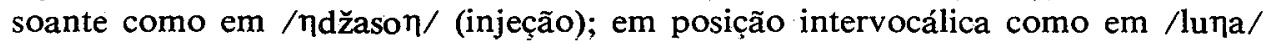


(lua) e em posição final. O equivalente crioulo das vogais nasais portuguesas é uma vogal oral seguida de $/ \eta /$. Sua presença é tão marcante que muitos estudiosos chegaram a interpretar as seqüências $/ \eta /$ mais obstruinte como un fonema prenasalizado. Com isso teríamos $/ \mathrm{mb}, \mathrm{mp}, \mathrm{nt}$, nd, etc/, como se vê em ROUGÉ (1988, p. 12).

No caso das vogais, notamos a ausência das nasais, já mencionada, que sempre se submetem à regra diacrônica $\tilde{\mathbf{V}} \rightarrow \mathrm{V} \eta$. Outra especificidade do crioulo é a ausência da distinção entre /e/ e /è/, bem como entre /o/ e / ò/. O som que substitui ambos parece ser algo intermediário, aproximando-se ligeiramente da vogal aberta.

No caso da estrutura silábica, há uma tendência à simplifição, já exemplificada na própria palavra que designa a língua, ou seja, / kiriol/ em vez de / $\mathrm{kriol} /$ (crioulo), como se diz no crioulo aportuguesado. Casos semelhantes são, entre outros, /garandi/ (grande), /tarbadžu/ (trabalho), /sukuru/ ("escuro", pronunciado "šcuro" pelos portugueses), etc. Estruturas complexas como CCVC (plástico) inexistem. É bem verdade que o fonema $/ \eta /$ pode constituir sozinho uma sílaba, como

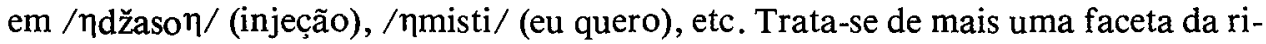
queza distribucional deste fonema.

No plano morfossintático, apresenta o crioulo tradicional muitas características próprias relativamente ao crioulo aportuguesado. Em primeiro lugar, não é comum a construção passiva. Frases do tipo "Amilcar Cabral matadu par protugis" (Amílcar Cabral foi assassinado pelos portugueses) são mais típicas do crioulo aportuguesado. Em geral o crioulo tradicional prefere ligar as orações com os conectivos coordenativos em vez dos subordinativos" (SCANTAMBURLO 1981, p. 69), como em "i padi kil pekadur e tchomadu Djon" (Ela gerou aquele homen o qual foi chamado João).

A reflexividade é indicada da uma forma toda especial. Vejamos como o equivalente de "suicidar-se" é expresso:

(a mi) $\mathrm{n}$ mata nha cabeça $=$ eu me mato

(a bó) bu mata bu cabeça = tu te matas

(el) i mata si cabeça = ele se mata

(a nós) nó mata nó cabeça = nós nos matamos

(a bós) bó mata bó cabeça = vós vos matais

(elis) é mata sé cabeça = eles se matam

E assim temos os pronomes pessoais em sua forma tônica (isolada), clítica e possessiva.

Construções como "n tene constipaçon" ou "n sta constipadu" (estou resfriado) só ocorrem no crioulo aportuguesando. O crioulo tradicional prefere dizer: 


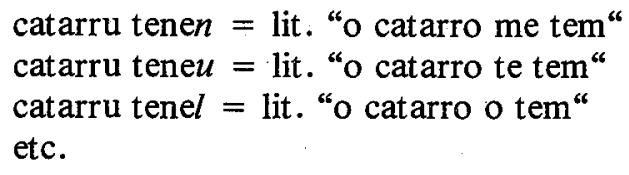

No que tange à flexão dos nomes, o crioulo tradicional não a possui nem para o gênero nem para o número. No crioulo aportuguesado ocorre o $-s$ de plural e o $a$ de feminino, além da flexão da grau "sinho" (inho).

Uma das características mais conspícuas dessa modiladade de crioulo é aquilo que chamo de "partículas exclusivas". Trata-se de intensificadores (SCANTAMBURLO 1981, p. 66) que ocorrem exclusivamente com determinada palavra ou morfema. Assim, "uak" só ocorre com "burmedju" (vermelho), isto é, "burmedju uak" (muito vermelho). A seguir apresento mais alguns exemplos com seus respectivos parceiros:

$$
\begin{aligned}
& \text { brancu fandan = muito branco } \\
& \text { pretu nok = muito preto } \\
& \text { i moja iop }=\text { está muito molhado } \\
& \text { i cala iem }=\text { está muito calado } \\
& \text { i firia iem }=\text { está muito frio } \\
& \text { limpu pus }=\text { muito limpo } \\
& \text { sucuru tip = muito escuro }
\end{aligned}
$$

A particula "iem"é uma excesão, no sentido de que ocorre com duas palavras diferentes. Estas partículas têm sido equivocadamente interpretadas como ideofones (cf. WILSON 1962, p. 34-35). No crioulo aportuguesado, no crioulo dos estudantes, praticamente não se usam mais tais partículas. Os estudantes, p. ex., Preferem dizer "muito sukuro", "muito limpu", etc.

O crioulo tradicional se distingue do crioulo nativizado e do crioulo aportuguesado de maneira insofismável. Mas, como se trata do "crioulo dos velhos" (Domingos), tende a desaparecer, cedendo o lugar para o crioulo aportuguesado, em mais um passo do processo glotofágico.

Há um tipo de narrativa popular em crioulo muito conhecido na Guiné-Bissau. Em geral as personagens são animais. Pelo menos duas coletâneas destas narrativas estão publicadas. Uma delas foi publicada na França por M. Emilio Giusti (cf. GIUSTI 1981). A outra foi publicada em Bolama (Guiné-Bissau), por MONTENEGRO/MORAIS (1979). Todos os textos destas coletâneas podem ser considerados como exemplificação do crioulo tradicional. Para terminar, transcrevo um pequeno texto da segunda antologia (p. 5). 


\section{SALTON KU SI MINJER \\ KA BO CORA INDA}

Un minjer sai pa da paña salton na roda di mar.

I ciga, i paña salton manga del, i fia na korda. I bin paña un salton e fia na korda.

Minjer di salton sai, i oja si ome, i ba cora janan lá na metade di tarafe. I na cora, i na cora, i fala si ome ku pañado, i na cora.

Salton fala si minjer:

- Ka bo cora. Ora ku bo sinti na ceru na iasadu bo ta cora, ma temente $\mathrm{N}$ ka iasadu inda, ka bo cora.

Minjer ku panal i ditanda gora korda e ba laba kurpu. Salton salta, i kapli na korda e mite dentru di koba. I fala si minjer:

- $\mathrm{N}$ tarda kontau. Temente bo ka na sinti ña ceru na fugu, sibi kumâ $\mathrm{N}$ ka muri.

\section{O SALTÃO}

E A MULHER

\section{NÃO É A HORA DE CHORAR}

Uma mulher sai para ir apanhar saltões à beira-mar.

Apanha muitos e à medida que os apanha enfia-os numa corda.

A certa altura surge a mulher de um saltão que, ao ver o seu homem na corda, corre aos gritos para o meio do tarrafe.

O saltão fala para a mulher:

- Não chores. Quando me sentires o cheiro a assado podes chorar à vontade, mas enquanto não te cheirar a queimado tem calma.

A mulher que estava a pescar estende a corda no chão para ir tomar banho. $O$ saltão aproveita para se escapar e enfia-se na sua cova.

E diz à mulher:

- Eu não te disse? Enquanto não sentires o meu cheiro no fogo, podes estar certa de que não morri.

\section{Crioulo aportuguesaso}

"Criol i língua mas fácil

di continenti africanu“

(Mário, popular nas ruas

de Bissau)

Como o próprio nome já diz, o crioulo aportuguesado é uma modalidade de crioulo fortemente influenciada pelo português. Meu informante sempre se referia a ele como "crioulo dos estudantes" ou "crioulo dos jovens". É também o que se chama de "kriol lébi" (crioulo leve), por oposição ao "kriol fundu" (crioulo fundo). Como acabamos de ver, este equivale ao que chamei de crioulo tradicional. Nas pala- 
vras de Domingos, "O crioulo falado pelos jovens é bem diferente do crioulo falado pelos velhos. Está mais próximo do português“. Ou, como disse um administrador de hotel, de formação superior: "O crioulo bem falado é parecido com o português". É o que Rougé chamou de "lusitanização", ou seja, "la lusitanisation dont le développement est surtout dû à la scolarisation en Portugais" (ROUGÉ 1988 , p. 8).

Com a devida cautela, talvez possamos afirmar que em referência ao crioulo aportuguesado são verdadeiras aquelas "definições" de crioulo legadas pela ideologia colonialista. Pelo menos parece ser o que têm em vista. Diante de enunciados como "Camaradas trabadjaduris, camaradas di no tera, camaradas trabadjaduris di Guiné!" (SCANTAMBURLO 1981, p. 109), somos tentados a aceitar firmaç̃̃es como "o crioulo é português errado" (M. F:), "o crioulo é português mal falado" (o povo) ou simplesmente "criol i portugis mal papiadu" (o povo).

Toda e qualquer mudança é encarada pelo status quo como deformação. A ideologia colonialista não poderia fugir a esta regra. Segundo Rougé $(1981$, p. 5), “à l'origine du kriol il y a vraisemblablement du Portugais mal parlé, de même qu'à l'origine du Portugais, du Français ou de l'Espagnol il y a du Latin mal parléc. E isso ninguém aceitaria nos dias de hoje. Por que, então, os próprios falantes de crioulo aceitam a idéia de que o crioulo é português mal falado? Simplesmente devido aos quase cinco séculos de dominação colonial. O colonizador europeu foi tão eficiente em sua política glotofágica que conseguiu impingir nos próprios nativos a idéia de que a língua européia é um bem para eles. Até mesmo o líder revolucionário Amícar Cabral estava de acordo com ela. É o que se vê no tantas vezes citado texto "O português (língua) é uma das melhores coisas que os tugas nos deixaram" ( $N \hat{o}$ Pintcha $21 / 2 / 76$, p. 9). O português é hoje praticamente a única fonte de neologismos para o crioulo. Virtualmente toda e qualquer palavra portuguesa pode ser usada em crioulo, com pequenas adaptações, do que dá uma pálida idéia o enunciado transcrito acima. Sempre que não se conhece (ou não se lembra de) alguma palavra em crioulo, usa-se o equivalente português. Ninguém o acha estranho. Aqui devo me reportar ao que foi dito a propósito dio crioulo tradicional. Ou seja, no crioulo aportuguesado usa-se com muita freqüencia a passiva do verbo, pode ocorrer flexão em gênero e número ('luta política", "trabadjaduris", etc."), muitos neologismos como "elicopter", "discordja“, etc. (SCANTAMBURLO 1981, p. 85). Com isso, toda o fonologia crioula se aproxima da portuguesa. Aqui já ocorrem os fonemas $/ \mathrm{z}$, $\lambda, \breve{s}, \breve{z} /$. A estrutura silábica também se complica, sempre na direção do português.

Até as artificiais e superficiais formas de polidez européias já estão sendo adaptadas para o crioulo (aportuguesado). Por exemplo, hoje não é raro ouvir-se "fássin fabur!" (faça-me o favor!), "obrigadu!", etc. Para se interpelar um desconhecido na rua se diz "amigo!", "primo!", "ermon!“ (irmão!), etc. Na Guiné-Bissau não é comum ouvir-se "patron!" ou "chef!", como no Senegal e na Costa do Marfim, por exemplo. 
Os dois únícos meios de comunicação de massa do país são o jornal Nô Pintcha e a Rádio Emissora Nacional. O primeiro é impresso inteiramente em português. As vezes ele até faz a apologia do crioulo, mas sempre em português. De vez em quando ele publica alguns poemas crioulos, e isso é tudo.

A REN tem programas em crioulo mas não apenas em crioulo. Há-os também em balanta, manjaco, mandinga, fula, felupe, bijagó, beafada, sosso e francês, além do português (a maioria). $\mathrm{O}$ fato é que há programas em crioulo. Como não poderia deixar de ser, é o melhor exemplo de crioulo aportuguesado. $O$ enunciado acima transcrito é o início de um destes textos, que está reproduzido em SCANTAMBURLO (1981, p. 109-112). Nas páginas 85 a 108 deste livro temos mais três exemplares de textos do crioulo aportuguesado.

Desse tipo de crioulo disse um diretor de liceu: "O crioulo falado no rádio é português mal falado. Eles metem um termo crioulo aqui outro ali, mas a maior parte das palavras são portuguesas". Depois ele acrescentou: "O crioulo bem falado, do rádio, só as pessoas que estudaram entendem. É muito parecido com o português". Por outras palavras, "crioulo bem falado" = "português mal falado", segundo esta ideologia.

Como já foi dito acima, o crioulo aportuguesado é também a linguagem usada nas repartições públicas, na redação do Nô Pintcha, nas reuniōes do partido, no pátio e no setor administrativo das escolas, etc. No contexto da sala de aula, no entanto, ele é proibido, havendo inclusivo punição para quem o usar. O uso do português é obrigatório. Por fim, é neste crioulo que se fazem as campanhas de saúde pública. Por exemplo, afixam-se cartazes contra a SIDA (AIDS), ensinando o uso de escovas de dentes, campanhas de vacinação, etc.

Eu fui informado oficiosamente em diversas oportunidades que Portugal obteve a concessão para instalar a televisão na Guiné-Bissau. Se isto efetivamente ocorrer, teremos mais um meio de propagação do crioulo aportuguesado, ao lado do português.

Sumariando, poderíamios afirmar que num futuro não muito distante o crioulo tradicional desaparecerá, cedendo o lugar ao crioulo aportuguesado. O prognóstico lingüístico, ou seja, a antecipação do que poderá eventualmente ocorrer com uma língua, não só funcionalmente mas também estruturalmente, é perfeitamente possível. Para tanto basta dispormos de certos dados concretos de caráter "sociológicolingüísticos" (NIKOL'SKIJ 1971, p. 233). Assim sendo, ao escrevermos qualquer ensaio sobre o crioulo da Guiné-Bissau, devemos levar em conta o crioulo tradicional. No entanto, maior ênfase deve ser dada ao crioulo aportuguesado, que é o crioulo moderno, o crioulo dos nossos dias. Aqui, como em qualquer lugar onde se aja cientifícamente, não cabe saudosismos. O dia em que não houver mais crioulo tradicional a distinção entre ele e o crioulo aportuguesado tampouco existirá. Poderemos dizer pura e simplesmente "crioulo". 
Além dos textos já mencionados, os que são produzidos por missionários com finalidades catequéticas também são ótimos exemplares de crioulo aportuguesado. Aliás; eles constituem a maioria dos textos escritos em crioulo em geral. Feitos pela igreja católica, posso citar, além de catecismos e textos menores, os seguintes:

a) Missal Ferial na Criol. Bissau: Diocese de Bissau, 1987. 348 págs.

b) Missal Dominical na Criol. Bissau: Diocese de Bissau, 1987. 319 págs.

c) Nobu Testamentu. Paskua di Jesus Kristu (em quadrinhos). Bissau: Komison Diosesanu di Katekesa, 1988.

Para uma longa lista de outras obras do gênero, cf. BIASUTTI (1982, p. XIII $-\mathrm{XIV)}$.

Há também textos de outras religiōes, como Bom Nova de Fidjo Deus. 1979. Soc. Unido (sic!) de Biblia, sem indicação de local de publicação. Como se vê pelos títulos, não há uma escrita uniformizada do crioulo. Cada um o escreve como bem entende. Um fato curioso a ser notado também é que grande parte do que se escreveu sobre o crioulo em geral foi feito por religiosos.

A seguir, reproduzo dois excertos desses textos religiosos e um dos textos políticos da REN, tirados de SCANTAMBURLO (1981).

5. Leitura di carta que S. Paulo scribi pa cristons di Colósse: $(3,1-4)$

Nha ermons, manera que bô lanta di morte cu Cristo, bô disidja caussas di céu, nunde que Cristo sta n'el, sintado na mon direita di Deus. Bô pensa na cussas di céu, ca bô pensa na cussas di terra. Pabia bô muri djá; i bó bida sta sucundido cu Cristo, na Deus.

Ora que Cristo, qui bó bida, i na bim manifesta, enton abós també bô na bim manifesta cu El na glória.

(Missal Dominical, p. 142).

\section{Leitura di livro di profeta Miqueias: $(5,1-4)$}

Ali quê que Sinhor fala: “Abô, Belém-Efratá, embora bu mas piquinino di terras di Judá, na bó i na bim sai quil qui na bim guia Israel na nha nome.

Si cumçada i di tempo antigo, di dias que ca pudi lembrado mas!“

El cu manda, Deus na bim abandona si povo, té na tempo que um mamé na bim padi um fidjo.

Enton resto di Israel na bim riba pa si terra.

El i na bim lanta, i na bim guia si povo cu força i na presença glorioso di nome di Sinhor, si Deus.

Enton povo na bim vivi na sussego, pabia si grandeça na bim tchiga té na cabantada di terra, i El i na bim spadja si paz na tudo lado.

(Missal Dominical, p. 280) 
I bai pa tudu parti pa tchoma tuga pa é odja realidadi ke di facto nó nesesitaba dja nan no independénsia, ma tuga pa resposta k'é ta daba Cabral i iera barcu k'é na saiba di Lisboa, avion k'é na bimba di Portugal caregadu di bomba, caregadu di bala i caregadu di tropa pa pudi ocupá tudu cantus i sentru di no tera...

...I na momentu dja ke tudu mobilizason staba dja feitu ku tuga sibiba dja cuma tudu povu staba preparadu pa guera i tuga cunsa cu se represon na tabanca, manda panha mindjéris, panha omi, manda mara, suta conta contá.

Foi para todos os lados para fazer ver aos Portugueses que realmente precisávamos da independência, mas a resposta que eles davam a Cabral, eram os barcos que saiam de Lisboa, aviões que vinham de Portugal carregados de bombas, de balas e de tropas para poderem ocupar todos os cantos e o interior da nossa terra. E no momento em que toda a mobilização já estava feita, em que os Portugueses já sabiam que o povo estava preparado para a guerra, os Portugueses comerçam com a repressão nas tabancas: entravam nas tabancas, mandavam prender mulheres, homens, amarravam-nos e batiam sem conta.

SCANTAMBURLO $(1981$, p. 86)

\section{Português acrioulado}

Em várias ocasiões houve falta de comunicação entre mim e meu informante, Domingos. Certo dia ele chegou e disse: "Eu estou doente hoje“. Quando lhe perguntei de quê, ele me respondeu que havia jogado muito futebol no fim-de-semana anterior, portanto, estava "doente". Só depois de muito tempo vim a descobrir que ele queria dizer que estava cansado. A expressão crioula "a mi n duensi" significa também "eu estou cansado". O português acrioulado adapta a cultura e os esquemas de raciocínio crioulos à expressão portuguesa. Num outro encontro, eu lhe disse qualquer coisa, mas ele não entendeu. Em seguida acrescentou: "O português do Brasil nos cansa" (portugis di Brasil i ta cansanu", traduziu ele a meu pedido). Mais tarde descobri que "a mi n cansa" quer dizer também "é difícil para mim", em crioulo. Outra vez o esquema de pensamento crioulo foi transposto para o vocabulário e a sintaxe protuguesa. É o português acrioulado.

Apesar da forte influência do francês, sobretudo do Senegal, todas as pessoas com um mínimo de informação falam português, freqüentemente com dificuldade e conn visível marca do criòulo, ou seja, falam o português acrioulado. Os falantes de crioulo entendem este portuguếs, mesmo que não o falem, como já vimos. Têm um domínio passivo do português acrioulado. Se falarmos pausadamente o nosso português a maioria deles nos entendem, mesmo aqueles que só se expressam em crioulo tradicional, isto é, os velhos. É o caso do velho vigia de uma pensão com o qual mantive ligeiro diálogo, eu falando pausadamente em português e ele me respondendo em crioulo. Na cidade balneárea de Babuque, no arquipélago de Bijagós, vi dois jovens conversando em português acrioulado sobre como conseguir uma casa segura para morar. $\mathrm{O}$ fato me chamou a atenção porque normalmente este diálogo seria em crioulo, ou então na língua nativa (bijagó). 
Há uma série de peculiaridades fonético-fonológicas que se notam com facilidade desde a primeira vez que se ouvem os guineenses falando português. Em primeiro lugar, pode-se dizer que do português lusitano para o português acrioulado vige a seguinte regra livre de contexto:

$$
\left[\begin{array}{l}
\check{s} \\
\check{z}
\end{array}\right] \longrightarrow\left[\begin{array}{l}
s \\
z
\end{array}\right]
$$

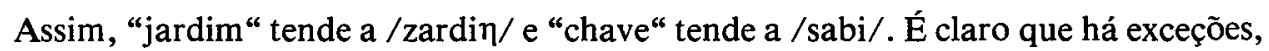
mas a tendência geral permanece.

Em segundo lugar, notamos uma tendencia à desnasalização das vogais nasais. A regra já mencionada $(\tilde{\mathrm{V}} \rightarrow \mathrm{V} \eta)$ tende a ser aplicada também no português acrioulado. Em terceiro lugar, a confluência da vibrante simples $/ \mathrm{r} / \mathrm{e}$ da múltipla $/ \overline{\mathbf{r}} / \mathrm{em}$ um único som, também vibrante múltiplo, não é rara. Finalmente, tende a desaparecer a distinção entre /e/ e /è/, por um lado, e entre /o/ e /ò/, por outro. Quando dizem "ele" e "senhor", p. ex., ouvimos algo como /'Eli/ e /si'ñòr/.

Expressões como "homen grande" e "mulher grande" para "velho" (subst.) e "velha" (subst.), respectivamente, são muito comuns. Trata-se da transposição de expressões crioulas. No livro do sociólogo Carlos Lopes podemos respigar algumas ocorências de expressões acriouladas (LOPES 1987). Melhores exemplos são, porém, as emissões radiofônicas em português e o jornal Nô Pintcha. No entanto, é no léxico que a influência do crioulo se mostra de modo mais facilmente palpável. Pertencem ao vocabulário do português acrioulado as seguintes palavras, dentre centenas de outras:

candonga $=$ micro-ônibus interurbano

poilon = árvore típica, muito grande

tabanca = agrupamento de casas, cobertas de palha, típicas

bolanha $=$ alagados onde se planta arroz

chebéu = óleo típico, próximo do dendê brasiliero

Para mais exemplos, pode-se consultar ROUGÉ $(1986,1988)$ e WILSON $(1962$, p. 6).

Português acrioulado é, assim, o português guineense. Assim como há o português lusitano, o brasileiro, o angolano e o moçambicano, há também o português guineense. É bem verdade que ele tem um número ínfimo de falantes (cerca de 300 , como vimos), mas é português. É o português enegrecido pelo sol escaladante do noroeste africano.

6. Português e outras linguas

Além do português acrioulado, há pelo menos mais uma modalidade de português que tem uma relativa importância na sociedade guineense. É o português lusi- 
tano. Isso tem suas causas históricas. Já no século XV os portugueses chegavam à costa ocidental africana, embora só no século XIX tenham começado a colonização propriamente dita. O fato é que bem ou mal, os portugueses estão na Guiné-Bissau há cerca de cinco séculas (LOPES 1987, p. 15-18).

Com movimento de libertação nacional, houve uma natural lusofobia. Mas isso já passou e os portugueses estão retornando ao país para retomar algumas propriedades, para estabelecer algum tipo de empresa e até para implantar uma rede de televisão. Nas "lojas francas" ou "interlojas“, grande parte dos produtos são importandos de Portugal. Enfim, Portugal voltou a ser uma referência para a GuinéBissau.

Um fato curioso é que grande parte dos jovens desejam estudar em Portugal. Alguns inclusive gostariam de se mudar para este país. Muitos dos que para lá foram não regressaram. Por outras palavras, Portugal tem uma grande força de atração sobre os guineenses. Conseqüentemente, o português lusitano é um ponto de referência. Tanto que há uma consciência de que o português guineense é mais próximo do lusitano do que do brasiliero, p. exemplo. Um funcionário do Ministério da Educação disse: "Os brasileiros falam diferente de nós. Nós falamos como os portugueses“, o que, aliás, não é inteiramente verdadeiro. O português guineense é o português acrioulado.

O Brasil só agora está se fazendo presente culturalmente. Várias bolsas de estudo têm sido concedidas a jovens guineenses. No começo deste ano (1988) foi inaugurado o Centro de Estudos Brasileiros, dentro da embaixada, o que vem despertando grande interesse na população de Bissau.

Depois do português, a língua mais presente na Guiné-Bissau é o francês. Aliás, ela é uma ilha de língua crioulo-portuguesa numa ragião de língua francesa. A Guiné-Bissau só tem fronteiras com o Senegal, do qual depende economicamente, e com a Guiné-Conacri, ambos de língua francesa. Nos hotéis, nas repartiçōes a até no mercado, pode-se encontrar gente que entende e/ou fala francês. A expressão 'voilà' e outras são muito freqüentes. Quando os guineenses se dirigem a um estrangeiro cuja nacionalidade ignoram, fazemi-no em francês. O Centro Cultural Francês foi dos primeiros a se instalarem em Bissau. Além disso, há o programa em francês na rádio, já mencionado. Não obstante tudo isso, o português, ou melhor, o português acrioulado, ou melhor ainda, o crioulo aportuguesado não está ameaçado (cf. MACEDO, a sair).

Devido à grande dependência da economia guineense em relação à senegalesa, a língua wolof também pode ser ouvida de vez em quando no mercado de Bissau. Há inclusive alguns raros guineenses que o entendem.

$O$ inglês só é sentido a nivel do fraco turismo. O espanhol é praticamente ausente, fato que não é atenuado nem pela forte presença dos cooperantes cubanos. 
IV - A seguir, apresento um quadro sinótico em que se pode visualizar a complexa realidade lingǘstica guineense, do ponto-devista diastrático. É claro que não há uma descontinuidade entre, p. ex., (3) crioulo tradicional e (4) crioulo aportuguesado. Na realidade trata-se de um continuum. Os pontos (1) a (6) são balizas a que podemos nos referir a fim de entendermós a Guiné-Bissau do ponto de vista lingüístico. Como já foi dito, a criação do estado guineense, bem como de praticamente todos os estados da África e do mundo em geral, significou a imposição de uma li-

(b) (c)

(a)

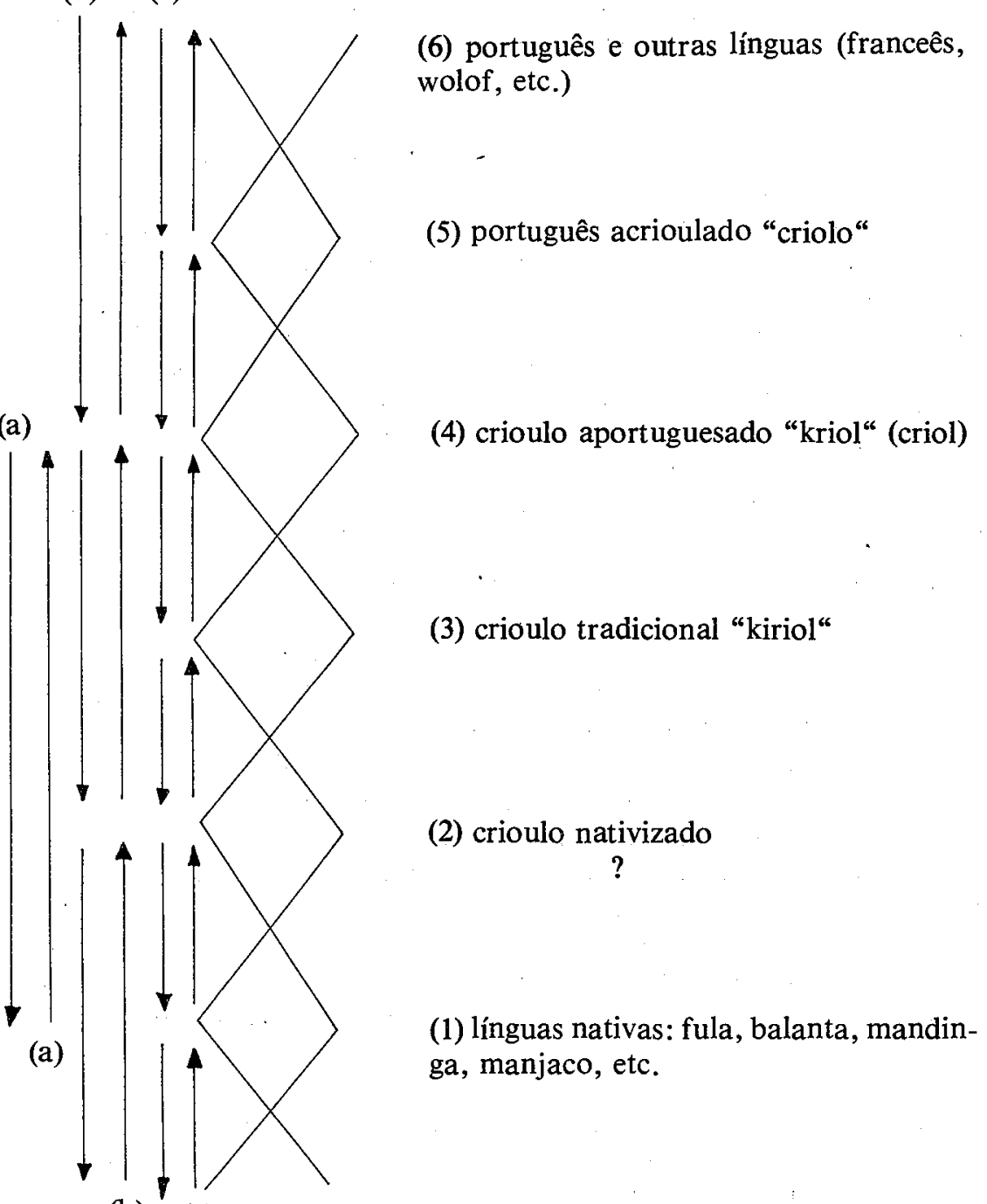

(b) (c)

Visão diastrática da realidade lingüística da Guiné-Bissau

Quadro 1 
mitição territorial que violentou a realidade étnica local. Assim sendo, se quisermos entender a situação sociolingüística desses países, temos que partir de um esquema também artificial (aliás, seria possível um esquema natural?).

Sendo a transição de um nível para o outro gradual, contínua, é natural que haja muita interinfluência, como mostram as setas (a)-(c'). De um modo geral, de (6) até (3) as influências preponderam na direção das setas (a), (b) e (c). Com efeito, já vimos que o português lusitano (6) é sempre um ponto de referência para o guineense, sua influência sobre o português acrioulado (5) é maciça. A ideologia colonialista incutiu na mente dos guineenses, cultos e analfabetos, que o português lusitano é a melhor linguagem, a mais correta, a mais perfeita (cf. a passagem de Amílcar Cabral acima transcrita!).

A influência "descendente" vai até às línguas nativas (1), passando por (4), (3) e (2). No mancanha, por exemplo, podemos citar os seguintes exemplos vindos do crioulo, que por sua vez os adaptou do português: /prata/ (prato), /ukaru/ (carro), /ubiñu/ (vinho), etc. (para mais exemplos, cf. WILSON 1962, p. 7-9). No sentido "ascendente", ou seja, das setas (a') a (c'), também há inúmeras ínfluências. Várias delas já foram referidas acima. ROUGÉ (1988) nos dá centenas de exemplos (cf. o que foi dito sob a rubrica "crioulo nativizado" (2) e "português acrioulado" (5)!).

De um modo geral, as influências se dão de um nível para o que lhe está imediatamente adjacente (subjacente ou super-jacente), como mostram as setas (c) e (c'). No entanto, ela pode se dar também entre níveis mediatamente adjacentes. É o que mostram as setas (a), (a'), (b) e (b'). Situaçðes em que o crioulo aportuguesado (4) e até o português acrioulado (5) podem influenciar as línguas nativas (1) são as emissões radiofônicas, o contato cidade-campo, a alfabetização de monolíngues nativos diretamente em português, etc.

O fato é que, do ponto-de-vista da Guiné-Bissau, na direção de (6) a (1) temos um continuum que vai do "menos natural" ao "mais natural" e vice-versa. A realidade originária, primeira, africana são as línguas nativas. Após um penoso processo colonial, o crioulo também se tornou um ingrediente relativamente natural do espaço africano chamado Guiné-Bissau. Mas, pairando sobre ele como una espada de Dâmocles sempre pronta para feri-lo (julgá-lo "português errado") está o português.

IV - Se é verdade que "es ist möglich, die funktionale Entwicklung von Sprachen zu prognostizieren“ (NIKOL'SKIJ 1971, p. 233), qual será o futuro quadro lingüístico guineense?

Como já vimos, a instauração do estado significa a aniquilamento das etnias (LOPES 1987, p. 19). Levando em consideração que os colonialistas impingiram nos colonizados a idéia de que a europeização é algo de bom, podemos prever com razoável margem de certeza que no futuro tudo tenderá para a direção ascendente 
das setas. Por outras palavras, os nativos tenderão a se aproximar do crioulo, enquanto que os falantes de crioulo tenderão a se aproximar do português. É bem verdade que as comunidades nativas são bastante fechadas e tendem a se defender contra a europeização. Mas, o processo "civilizatório" tem uma força tão avassaladora que nem elas estão imunes a ele. Quanto aos falantes de crioulo, ou seja, aqueles que já estão desenraizados de suas etnias, a aproximação ao português sempre significa a possibilidade de ascensão social. Com efeito, ninguém pode ter um emprego público sem dominar o português (SCAMTAMBURLO 1981, p. 15).

Resumindo, podemos dizer que no futuro haverá uma tendência no sentido de os falantas de linguas nativas passarem a falar o crioulo (cf. SANTOS 1987, p. 12). Os falantes de crioulo (tradicional) tenderão a se aproximar do crioulo aportuguesado e do português acrioulado. O português lusitano permanecerá, pelo menos por algum tempo, como o ponto de referência último. Esquematicamente, o processo pode ser represendato da seguinte maneira:

\author{
6. português lusitano \\ $\uparrow$ \\ 5. português acrioulado \\ $\uparrow$ \\ 4. crioulo aportuguesado \\ $\uparrow$ \\ 3. crioulo tradicional \\ $\uparrow$ \\ 2. crioulo nativizado \\ 1. línguas nativas \\ Quadro 2
}

Lingüísticamente, o processo que se desenrola na Guiné-Bissau pode ser caracterizado como de crioulização-descrioulização. Por um lado, de (1) a (3) temos a aproximação dos falantes de línguas nativas ao crioulo, ou seja, uma continuarcão do processo de crioulização iniciado já no périodo colonial. Por outro lado, de (4) a (6) temos o processo contrário, de descrioulização, ou seja, de aproximação ao português. É da dinâmica destes dois processos que teremos o futuro lingüístico da Guiné-Bissau.

Devemos acrescentar que o movimento historico é dialético. Assim sendo, mesmo que no futuro surjam movimentos nacionalistas, de valorização da cor local, pode-se prever que a Guiné-Bissau não sairá ilesa do processo de mundialização da cultura. Repitamos aqui que os meios de comunicação de massa têm um poder irresistível. Mesmo que o rádio, a televisão (que em breve será instalada) e o jornal tenham programas, ou seções, em línguas nativas e em crioulo o processo não será evitado. 
O fato de haver programas em línguas nativas é uma faca de dois gumes. Se por um lado valoriza a língua, por outro modifica-a por completo, pois surgirão inevitavelmente uma fraseologia e um vocabulário internacionais. Com eles vem toda uma cosmovisão diferente (europeizante) da nativa.

Quando se considera o estado, verifica-se que a força do poder é tão grande que chega mesmo a se transformar no poder de uma força que enquadra todos no processo uniformizador. Em termos lingüísticos, este processo é sempre glotofágico.

$$
\text { V - Bibliografia }
$$

Baruffaldi, Mário. 1984. Criolo. Esboço de Gramática. Missão Católica.

Calvet, Louis-Jean. 1984. Linguistique et Colonialisme. Petit Traité de Glottophagie. Paris: Payot.

Djaló, Ibrahima. 1987. "Contribuição para uma reflexão: educação, multilingüismo e unidade nacional". Soronda 3. 101-111.

Giusti, M. Emilio. (org.). 1981. Contes Créoles de Guiné-Bissau. (Équipe de linguistique descriptive de l'UER, Univ. de Lyon). Paris: Conseil Internatịonal de Langue Française.

Lopes, Carlos. 1987. A Transição Histórica na Guiné-Bissau. Do Movimento de Libertação Nacional ao Estado. Bissau: INEP.

Macedo, Francisco (a sair). "O problema das línguas na Guiné-Bissau“.

Montenegro, Teresa \& Morais, Carlos de (orgs.). 1979. Junbai. Bolama: Imprensa Nacional/INACEP.

Nikol'skij, L. B. 1971. "Prognose und Planung sprachlicher Entwicklung“. In: Kjolseth, R \& Sack, F. (orgs.). Zur Soziologie der Sprache. Opladen: Westdeutscher Verlag, p. 229-237.

Rougé, Jean-Louis. 1986. "Uma hipótese sobre a formação do crioulo de GuinéBissau e da Casamansa". Soronda 2. 28-49.

1988. Petit Dictionnaire Etymologique du Kriol de Guiné-Bissau et de Casamance. Bissau: INEP.

Santos, Mário. 1987. "Algumas considerações sobre a nossa situação sociolinüística“. Soronda 4. 3-14.

Scantamburlo, Luigi. 1981. Gramática e Dicionário de Lingua Criol da GuinéBissau (CGR). Bologna: Ed. Missionaria Italiana.

Wilson, W. A. A. 1962. The Crioulo of Guiné. Johannesburg: Witwatersrand University Press. 


\section{Povzetek}

\section{KREOLŠČINA V GVINEJI IN NJEN ODNOS DO PORTUGALŠČINE IN DO JEZIKOV DOMORODCEV}

Jezikovna situacija v Gvineji (Guiné-Bissau) je močno zapletena. Razen jezikov domorodcev in kreolščine se govori portugalščina, tudi luzitanska portugalščina, vendar ponajveč kreolizirana portugalščina, in celo drugi jeziki, kot francoščina ali wolof. Za kreolščno je mogoče ugotoviti neki zgodovinski razvoj, kakor tudi zemljepisno razvejanost; sociolingvistično pa je še mnogo pomembnejša razčlenjenost na različne socialne plasti.

Avtor je opazoval reakcije govorečih, analiziral živi govor in maloštevilna zapisana besedila v kreolščini; zaradi sedanjih razmerij med posameznimi jeziki in govori sklepa, da bo prišlo do dekreolizacije, kar vodi k nekemu stadiju evropeizacije, vsekakor pa pomeni izgubo afriške identitete. 